\title{
A Call for Arms! Supplying the Sultan's Army, 1916-1918
}

JuLian BenNett (D

\author{
Department of Archaeology, Ihsan Dogramaci Bilkent University, \\ Ankara, Turkey;
}

A common feature of Turkey's principal military-focused museums and of many local ones also, are displays of military equipment used in the First World War and in Turkey's War of Independence (1919-1923). In many cases these are rifles and bayonets supplied by Germany to the Ottoman Empire during two specific periods: from 1887 to 1903 , when Germany supplied all the modern infantry weaponry used by the Ottoman army; and from 1916 to 1918, when Berlin answered the request from Constantinople for the latest models of their own small arms. This article looks into the circumstances behind that request and the German response, with a focus on the bayonets that were provided, as these are most often seen in places open to the public today. In addition, a brief account is provided on how these rifles and bayonets remained in service use, often in a modified form, until the 1950 .

KEYWORDS Seitengewehr 98/05; Gewehr 98; Waffenfabrik Mauser

\section{Introduction}

The field of World War One studies in Western Europe has a frankly embarrassing wealth of published English-language material available ranging from the experiences of individual soldiers to the wider-ranging accounts of tactical, strategic, and even logistical studies. Less well known is the Ottoman side even though 'The most amazing thing about the Ottoman army in the First World War is that an army which had been beaten comprehensively by four small Balkan states a year earlier [i.e., I913], managed to fight for as long as it did and as well as it did'. This is a truism that demands reflection. It is also one that brings us back to a fundamental aspect of industrialised warfare, the weaponry of the individual soldier, a subject we address here directly with regard to the Ottoman army during the period I9I6-I9I8.

We start with some generally, if not universally, accepted facts. In August I9I4 the Ottoman army had active numbers of about $180-200,000$ men in two classes, the regular army (Nizamiye) and the active reserve (Redif). When fully mobilized, that is 
with its home reserve units and irregular forces (Müstahfız), it consisted of perhaps as many as $700,000-800,000 .{ }^{2}$ By I9I 6 , though, it was in a state of some disarray; it had lost many thousands of its best trained and armed troops, its core regulars and those then serving their conscription period of three years. ${ }^{3}$ For example, the ill-fated I9I4-I9I 5 winter campaign in Eastern Turkey and the Caucasus had resulted in some 72,000 casualties. ${ }^{4}$ Even the most successful Ottoman campaign of them all, Gallipoli in I91 5, cost another 90,000 or so dead. ${ }^{5}$

The loss of manpower was one thing. It could be replaced to an extent by calling up reservists and by the regular annual levy of conscripts, which in theory supplied some 70,000 men a year. ${ }^{6}$ What could not be replaced so easily was the loss of materiel, an unavoidable consequence for any army in any campaign, but especially so for the Ottoman army as the winter campaign of I9I4-I5 saw it pushed back from the Caucasus into Eastern Anatolia. At the time the Ottoman soldier's principal firearm was a rifle of some form produced by Waffenfabrik Mauser of Oberndorf am Nekar (hereafter usually simply WFM). That is to say one of a total of 900,000 of the WFM Models I887, I890, I893 and I903 rifles supplied to Constantinople between I 886 and 1908,7 replacements for the single-shot Providence Rhode Island-made 'PeabodyMartini', which had served so well during the siege of Plevna in 1877 in the ninth Russo-Turkish War. ${ }^{8}$ Of these WFM products, the 270,000 Model I887 rifles were 'modern' in the sense that they had a tubular magazine with eight rounds, but were distinctly old-fashioned in using a black-powder cartridge in $9.5 \mathrm{~mm}$ calibre; by I9I4 they were used probably for training purposes only. The other three models can be classed as fully-modernised for the time, in having a stacked magazine system with five cartridges of the smokeless $7.65 \mathrm{~mm}$ cartridge system, also developed by WFM. ${ }^{9}$

The loss of countless numbers of these fully modern weapons in the winter campaign of I9I4-I9I 5 and elsewhere meant that by October I9I 5 some of the units of the Ottoman army employed at Gallipoli, and presumably in other parts of the Empire, were equipped with those examples of the officially obsolete versions of the Peabody-Martini rifle modified extensively in I9IO-I9I I to fire the WFM $7.65 \mathrm{~mm}$ cartridge. ${ }^{\mathrm{IO}}$ The result at Gallipoli was that many Ottoman troops there were using a single-shot rifle against British and Commonwealth forces armed almost entirely with the 'Short, Magazine, Lee Enfield Mk I' rifle, better known as the 'S.M.L.E.', with its Io-shot magazine. In tactical terms it was, frankly, a ludicrous situation. Yet it serves to remind us of just how successful the strategy of the German and Turkish field officers at Gallipoli was, far superior to that of their Allied peers, in enabling a successful conclusion to that campaign on Ottoman terms in spite of the reliance on under-armed and poorly-resourced but heroic fighting units.

\section{Germany comes to the rescue}

The situation regarding the supply of modern infantry rifles to the Ottoman army was improved somewhat after September I9I 5 when Bulgaria entered the First World War 


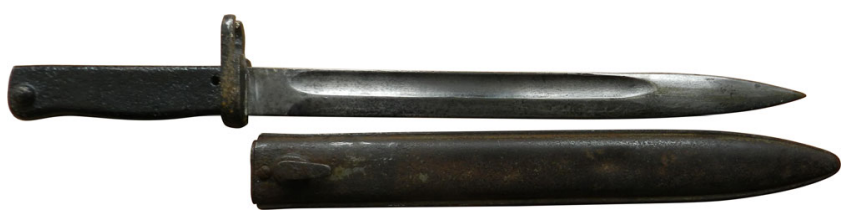

FIGURE 1. An 'Ersatz' bayonet, type EB 7 bis, as supplied to Turkey in 1916 (author's photograph).

on the side of the Central Powers, opening up a direct transfer route from Germany and the Austro-Hungarian Empire to Constantinople. By January 19I6, Germany was supplying the Ottoman Empire with WFM rifles captured from Belgium during the invasion of I9I4 and Mosin-Nagant rifles taken from the Russians after the victories at Tannenberg and elsewhere on the Eastern front. ${ }^{\text {II }}$ Even so, as a British Military Intelligence report on the Ottoman Army for I9I 6 noted, it was seriously under-armed in terms of modern infantry weaponry. Although it states there were 500,000 WFM Models I 890, I 893 and I903 rifles currently in service with the Sultan's armed forces, there was also a wide variety of other obsolescent types in use. These included 200,000 WFM Model I 887, about 500,000 'Martini-Henry [and] Martini-Peabody rifles', of which 370,000 were probably Peabody-Martini rifles converted to fire the WFM $7.65 \mathrm{~mm}$ cartridge, the others presumably Constantinople-made clones of the Martini-Henry of a $9.5 \mathrm{~mm}$ calibre, and 'considerable numbers of Remingtons and Winchester repeating rifles', black powder weapons in equally obsolete calibres that Ottoman Turkey had imported in the 1870 s and 188 os. $^{\mathrm{I} 2}$

Something had to be done to resolve this matter of a lack of modern weaponry as well as the variety of armaments and cartridge types used by the Ottoman army. Hence the request of the Ottoman High Command to Germany sometime before May I9I 6 for a supply of its standard infantry rifle, the Gew.98. ${ }^{\text {I3 }}$ This request was rejected initially: the Deutsches Heer was itself in the process of re-arming their own front-line and reserve troops with this rifle as well as replacing their own battle losses. ${ }^{\mathrm{I}}$ Instead, Germany agreed to send those stocks of its older Gew.88/05 (and possibly Gew. 88/I4 also) now withdrawn from front-line and rear-echelon service with the Deutsches Heer. The exact numbers are unclear. Perhaps as many as 50,000 were sent by the summer of I9I6, with another I70,I30 'ready for shipping' by November I9I7, and so around 220,000 in all during a roughly I 7 month period. ${ }^{\mathrm{I}}$ Absolute figures aside, these rifles were provided apparently with one or other version of the all-metal bayonet produced in Germany between late I9I4 and late I9I 5 as a temporary measure to make up for the lack of regular-issue wooden-hilted ones. No records apparently survive of how many of these so-called 'Ersatz' bayonets, officially known by the German military as the Aushilfs-Seitengewehre 88/9 8 to indicate they were 'temporary' bayonets that fitted both the Gew 88/I4 and Gew.98, were sent to Constantinople, but 'many thousands' were held in the armouries of the Turkish army until the I970s, when despatched for sale in the USA. ${ }^{16}$ Indeed, examples can be seen often today in Turkish antique shops, the great majority of those 
observed by the writer in Ankara and Istanbul being the type classed by Carter as the 'EB 3-I3' (Figure I), ${ }^{\mathrm{I}}$ a few with Ottoman-style numerals on the crossguard

\section{A renewed relationship}

The May r9I6 agreement did, however, include a consolation prize of sorts. This was that as from that same month, Germany would supply its Ottoman allies with those 'surplus' numbers of Gew.98 above a daily figure of 2,200 that WFM and the Deutsche Waffen-und Munitionsfabriken (DWM) of Berlin were required to supply to the Deutsches Heer. Indeed, as a taster, as it were, the first 6,000 Gew.98 were despatched to Constantinople that very month, renewing the relationship between Ottoman Turkey and WFM, the provider of the Turkish rifle Models I887, I890, I 893 and I903, and much of the Empire's rifle ammunition also, including that used in the modified and updated Peabody-Martinis. As with the supply of Gew. 88/05 to Ottoman Turkey, there is no agreed figure for the total number of Gew.98 supplied to Constantinople between I9г 6 and г9г 8 , although it was certainly in the order of

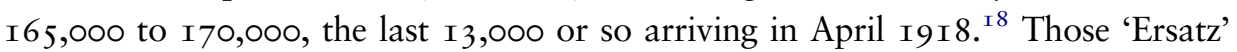
bayonets provided to the Ottoman Empire when it received its allocation of Gew.88/ 05 rifles would fit the Gew. 98 also, but it is probable that from the beginning, many Gew.98 were despatched with the current model of German bayonet, the Seitengewehre $98 / 05$ or $S .98 / 05$ for short.

\section{The S.98/05}

This particular model bayonet was introduced originally into service with the Deutsches Heer in 1905 as a 'tool-cum-weapon'. Hence its $36.5 \mathrm{~cm}$ long macheteshaped blade, which to some resembles a butcher's knife, ${ }^{19}$ which broadened gradually from $2.6 \mathrm{~cm}$ wide at the crossguard, to $3.4 \mathrm{~cm}$ at $28.5 \mathrm{~cm}$ along the blade, before narrowing to a spear-point tip with a $7 \mathrm{~cm}$ long false edge. As one official account described it, it was a Hiebewaffe' or 'chopping weapon', ${ }^{20}$ designed specifically for those troops who needed such a blade for cutting down underbrush for one or other reason. That is why it came in two versions (Figure 2), one with a sawback and so designated the $5.98 / 05 \mathrm{mS}$ ( $m S=$ mit Säge = 'with saw'), for issue explicitly to Pionier- and Eisenbahntruppen (Pioneer and Railway units), the other, with a plain back, for Fußartillerie and Telegraphtruppen (Foot artillery and Communications units.). ${ }^{2 \mathrm{I}}$

Soon after World War One began, however, it become increasingly apparent to the Prussian War Ministry that the then standard infantry bayonet, the S.98, with its pipe-backed blade, $52 \mathrm{~cm}$ long and $20 \mathrm{~cm}$ wide at the crossguard, was totally unsuited for combat use. For one thing, there was its unwieldy length, a holdover from an era when soldiers faced cavalry charges while standing upright. Another problem was its lack of a suitable cutting edge. Most conclusive of all, though, was 
how combat experience by the German Ostasiatisches Expedition-Korps during the Boxer campaign of I 899-I90 I had shown that the blade bent too easily 'particularly when stabbing through the thick winter clothing of the Chinese'. ${ }^{22}$

For these reasons the Prussian War Ministry decided to replace the 5.98 as the standard infantry bayonet with the shorter, stronger and all-in-all more versatile S.98/05, the sawback version being issued to senior NCO's as much as a status indicator as a 'tool-cum-weapon'. ${ }^{23}$ On I I ${ }^{\text {th }}$ September I9I4 it cancelled its outstanding contracts for the manufacture of the $S .98$ by the Suhl Consortium of weapons makers (i.e., G.G.Haenel, J.P.Sauer, and V.C.Schilling) in favour of the S.98/05, and by $3^{\text {rd }}$ October, likewise with the various Solingen concerns also producing this bayonet, and were even requesting the Suhl factories specifically to speed up manufacture of the $S .98 / 05$ as this was urgently needed to replace the $S .98$ on the grounds that it was a much better 'Hiebewaffe' or 'chopping weapon'. ${ }^{24}$ Bavaria, as usual, though, was dilatory in responding to Prussian-directed changes in anything military related, as a means of proving its 'independence' from Prussia. Thus it was not until the $2 \mathrm{I}^{\text {st }}$ January I9I5 that the Königliche Bayerische Gewehrfabrik (Royal Bavarian Armouries) at Amberg formally halted production of the S.98 in favour of the $S .98$ / $05 .{ }^{25}$ Meanwhile, by II $^{\text {th }}$ December I9I4, the Prussian Kriegsministerium had started to issue contracts for as many as two million 98/05 bayonets to other companies, including 800,000 each from Mauser Waffenfabrik of Oberndorf and the Deutsche Waffen- und Munitionsfabriken (DWM), the remainder by the Suhl Consortium. $^{26}$

\section{The Waffenfabrik Mauser S.98/05}

Waffenfabrik Mauser was, of course, Germany's foremost rifle-maker, and had no experience in producing edged weapons such as bayonets. Thus the bayonets supplied to the Ottoman Empire in earlier times with WFM rifles were made by a variety of makers, two in Solingen and three in Suhl. The company's interest in the $\mathrm{II}^{\text {th }}$ December I9I 4 contract was purely because it was a twinned commission, the other part being for the production of 800,000 Gew. 98 , the equal number of bayonets for these being of secondary importance as far as WFM were concerned. ${ }^{27}$ By $24^{\text {th }}$ April I9I 5 , however, it seems seems to have taken over the contract for the same number of rifles and bayonets won originally by its partner firm DWM. Such is indicated certainly for bayonet production as on that day they rented part of the premises of Unionwerk Mea G.m.b.H. Elektrotechnishe Fabrik Eisenwerk at Feuerbach, in north-west Stuttgart for a period of five years from I ${ }^{\text {st }}$ July I9I 5 to I ${ }^{\text {st }}$ July I920 specifically for the production of between one and a half and two million Blankwaffen und Seitengewehre - 'edged weapons and bayonets'. ${ }^{28}$ As no example of a WFMmade sword has ever been recorded, the Feuerbach premises were evidently used entirely for S.98/05. The terms of the lease were a rent of I Mark per bayonet to cover the cost of power, heating and lighting, payable on the $15^{\text {th }}$ of each month. It 


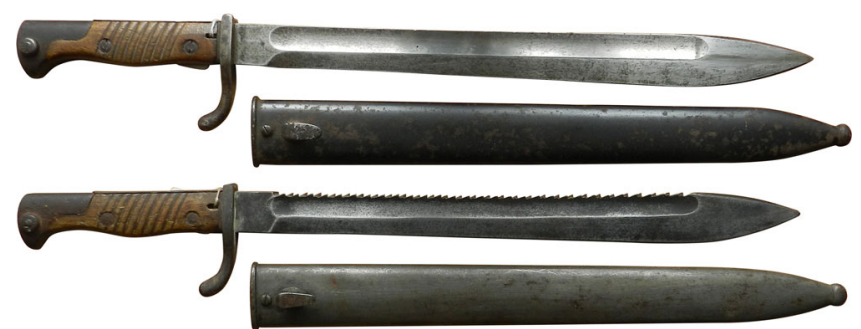

FIGURE 2. A regular Waffenfabrik Mauser S.98/05 (above) and the sawback version, the S.98/ $05 \mathrm{mS}$ (below) (author's photograph).

would seem, though, that WFM were slow, at least in the beginning, with their payments, and quite incidentally supplies us with an indication of the rate of bayonet production at Feuerbach. To be precise, a request from Unionwerk to WFM dated $8^{\text {th }}$ February I9I6 notes that $20,400 S .98 / 05$ had been manufactured there in December I9I 5, with a further I7, I 50 in January I9I6, making a total of 37,550 for which the payment of 37,550 Mark was requested. More interesting, though, is how this signifies a remarkable production rate achieved by WFM within a remarkably short time, given how two other makers of the same bayonet type, Haenel and Schilling of Suhl, both of which had produced S.98/05 before I9I4, and so already had the appropriate machinery and trained operators in place, could only manufacture 350 S.98/05 bayonets a day each in November I9I $4 .{ }^{29}$

Such a rapid increase in production by WFM could only result from a huge investment in machinery and the men with the skills to operate it. As far as it is known, there are no details regarding this part of their operations in the WFM archives. The company presumably used what was the then standard method of bayonet manufacture, as employed at the Wilkinson Sword Company in the late I88os, the most detailed account of contemporary edged-weapon manufacture known to exist. ${ }^{30}$ To begin with was the need for billets of high-carbon steel suitable for taking a sharp edge. The official specification for those S.98/05 made by Haenel of Suhl from 1905 onwards confirm this was the case, as does the detailed metallurgical analysis of an unmarked I9I 5-made S.98/05, while the XRF analysis done of a WFM version indicates an elemental composition conforming closely to these, suggesting it was also made of an equivalent quality high-carbon steel. ${ }^{3 \mathrm{I}}$ It is reasonable to assume that, as in the Wilkinson Sword Company's production system, these arrived at the factory in ready-made made bars that were then cut into billets of the appropriate size and forged into a blank or mould complete with fullers. ${ }^{32}$ After trimming, the blade part was heated to around I000-I $200^{\circ} \mathrm{C}$ and machine-hammered to the required thickness and length, before re-heating for passing through roller-shapers giving the blade its specified final length and profile complete with fullers. Grinding, using revolving stone wheels, then removed the excess metal to produce the final form, the addition of the saw teeth to the $S .98 / 05 \mathrm{mS}$ involving (we assume) machine stamping and then sharpening. Finally, the blade part was re-heated to a temperature of around 
$35{ }^{\circ}-375^{\circ} \mathrm{C}$ and tempered by plunging it into oil, ${ }^{33}$ before fitting the grips, the locking mechanism, the flash guard or Schutzbleche in examples made after August I9 I 5 , and a final polish. ${ }^{34}$

The necessary machinery for making the $S .98 / 05$ blanks was presumably supplied by WFM itself who could provide also men trained in the process of metal-casting, mouldforming, and steam-hammering. Less obvious is where the skilled manpower required for fashioning edged weapons such as the $\$ .98 / 05$ came from, a procedure requiring experienced grinders and polishers. While it is true that early $20^{\text {th }}$ century Germany was famous for producing high-class cutlery, the principal centre for this was Solingen, some Ioo km distant, which in I9I 3 supplied almost $60 \%$ of the world market with such items. ${ }^{35}$ Despite the increasing industrialisation of Germany, however, the making of cutlery, scissors, razors, and other like items at Solingen was even as late as 1907 based essentially on the local 'kotten industrie' system via the 'putting-out' method, by which by which large steel factories supplied the blanks made by semi-skilled workmen for artificers in smaller concerns to turn into finished items. ${ }^{36}$ As the German armaments industry geared up for war-time production, it is likely that many of these artificers found work at the Solingen-based companies of Coppel, Lüneschloss, and Weyersberg-Kirschbaum, now charged also with manufacturing S.98/05. ${ }^{37}$ As WFM had won a contract to supply over I,500,000 such bayonets over the next five years, at a cost to the German government of $16,960,000$ Mark, the largest of its kind in wartime Germany, ${ }^{38}$ one might reasonably speculate the firm was in a position to pay sufficiently trained grinders and polishers to move from the Solingen area to Oberndorf.

Be that as it may, production at Feuerbach evidently began in August 1916, as is shown by documentary evidence and by the existence of a few WFM S.98/05 a.A, or 'alter Arte', that is, examples, made to the original specifications without the 'flash guard' on the back of the grips. ${ }^{39}$ By the end of I9I6, WFM had produced a total of 373 , I00 S.98/05 at the Feuerbach works, with 493,900 more in $1917 .^{40}$ The indications are that after an initial slow start, with between I7,I 50 and 20,400 S.98/05 made each month, as many as 40,000 a month were being turned out by the end of 1917. On the basis of what is admittedly a very limited sample set, however, this greatly increased rate of production after I9I 5 perhaps saw a slight change in manufacturing standards. Of a total of 25 WFM S.98/05 bayonets date-marked between I9I 5 and I9I 8 and inspected by the writer, ${ }^{4 \mathrm{I}}$ four dated to I9I 5 weigh 53.2 to $54.2 \mathrm{~g}$., with the broadest part of the blade $3.45 \mathrm{~cm}$, compared to the officially specified weight of $5 \mathrm{I} .5 \mathrm{~g}$. and width of $3.45 \mathrm{~cm}$. All those made between I9I6 and I9I 8 are somewhat heavier, ranging from 56.0 to $59 . \mathrm{I} \mathrm{g}$, although the broadest blade part is narrower, ranging from $3 . \mathrm{I}$ to $3.3 \mathrm{~cm}$, while one only, dated $19 \mathrm{I} 7$, is at the official width of $3.45 \mathrm{~cm}^{42}$

\section{Waffenfabrik Mauser S.98/05 markings}

As with all other German regulation bayonets, all WFM S.98/o5 were marked on the blade back near the crossguard with the Prussian Abnabmestempel, the official 


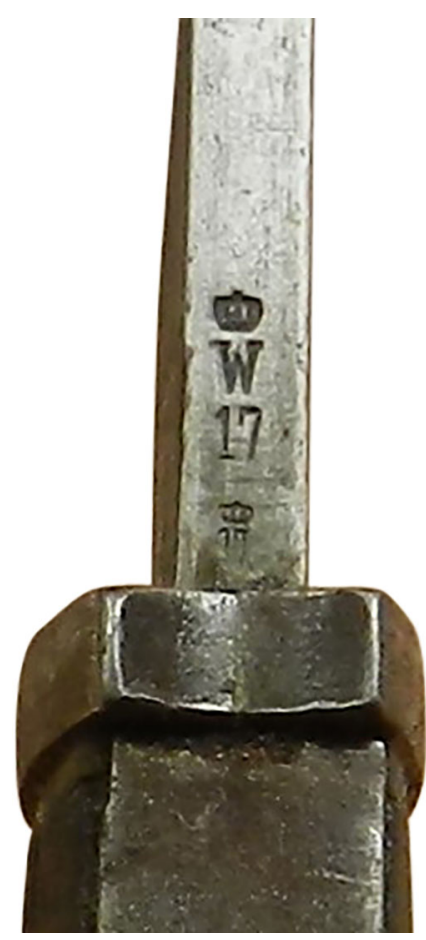

FIGURE 3. The Abnahmestempel on the blade-back of a Waffenfabrik Mauser S.98/05 made in 1917 (author's photograph).

acceptance marks indicating inspection and acceptance for service by the dulyappointed inspectors (Figure 3). These consisted of a crown over a 'W', for Wilhelm II, King of Prussia and Kaiser of the Deutsches Reich; below this the last two numbers of the year the bayonet was approved for issue; and then a smaller crowned 'Gothic' letter, the so-called fraktur or inspector's mark, representing the initial letter of the inspector's surname, which in the case of the WFM bayonets was a 'W'. This fraktur was applied after the blade had been tested and approved for further work, one or two examples of the same mark being found on the left-hand side of the pommel above the rifle catch system (Figure 4), to denote other stages in the inspection process.

Just as was the case with almost all German World War One bayonets made by private companies for the Deutsches Heer, those made by WFM were stamped on the right side of the ricasso with their mark. It was one of three variations in size, font, and spacing of the legend WAFFENFABRIK/MAUSER-A.G./ OBERNDORFa.N (Figure 5). On bayonets made between I9I 5 and I9I6, it usually measures around $8 \times 20 \mathrm{~mm}$, while bayonets made in I9I7 and I9I 8 are slightly larger, at $9 \times 23 \mathrm{~mm}$. Similar stamps are found on the reverse of the steel scabbards which these bayonets were issued with, ${ }^{43}$ although in this case four variations are known, again varying in size, font, and spacing, and some with a Maltese cross or a five-pointed star added, three of these versions measuring $6 \times 9 \mathrm{~mm}$, the fourth 


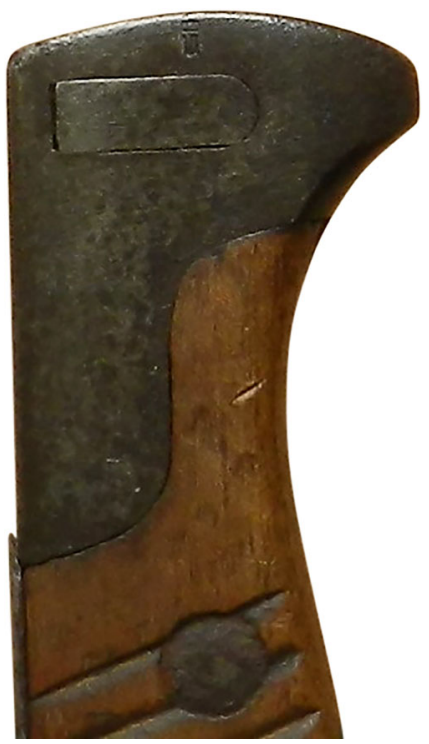

FIGURE 4. The fraktur mark on the pommel of a Waffenfabrik Mauser S.98/05 (author's photograph).

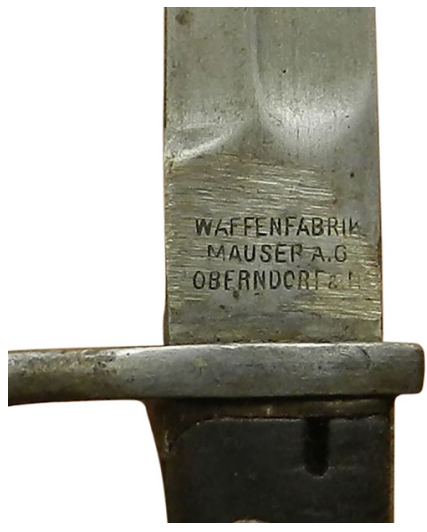

FIGURE 5. A typical maker's mark on the ricasso of a Waffenfabrik Mauser S.98/05 (author's photograph).

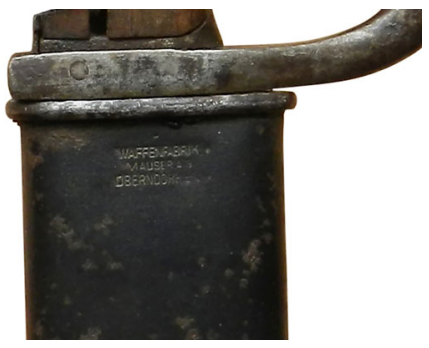

FIGURE 6. A typical maker's mark on the scabbard for a Waffenfabrik Mauser S.98/05 (author's photograph). 
$7 \times$ I $5 \mathrm{~mm}$ (Figure 6). Scabbards were and are interchangeable, so it is impossible to know if a bayonet mark and a scabbard mark combination known today is in its original form.

\section{From Oberndorf to Constantinople}

As we have seen already, the agreement made in May I9I 6 between Germany and the Ottoman Empire specified that Germany would supply its ally with all those Gew.98 above the 2,200 produced on a daily basis by WFM and the DWM concern. It seems reasonable to assume that each shipment of rifles from WFM came with the requisite number of their in-house bayonets, the only certain figure being that at least I 16,000 were sent to Turkey in the course of I91 $7 .{ }^{44}$ None of the WFM S98.05 despatched to the Ottoman Empire were marked in anyway to indicate Ottoman ownership as was the case with the Model I887, I890, I893 and 1903 rifles supplied by WFM, unlike the bayonets supplied by the weapons makers of Solingen and Suhl, which have a series of markings that denote Ottoman ownership. In the case of the bayonets, these included inter alia the Sultan's tughra or royal mark on the right side of the pommel, and a star and crescent on the blade spine as well as the right or outer face of the crossguard, which also had a serial number in Ottoman numbers on the left or inner face. No such markings have yet been recorded on any WFM S.98/05 seen by the writer, although a very few examples do have a small crescent mark on the right or outer face of the crossguard, and a few more have serial numbers in Ottoman digits on the left or inner face of this part. In none of these few cases, however, can we be certain the marks were applied before the Ottoman capitulation in I9I 8 , for as we will see, the $\$ .98 / 05$ remained in service use between then and Atatürk's script reform of 1928 and after.

As already indicated, the last $\mathrm{I}_{3}, 000$ or so WFM Gew.98, presumably with the same number of bayonets, were despatched to Constantinople in April I9 $8 .{ }^{45}$ Some of the $S .98 / 05$ made by the company and supplied to Ottoman Turkey in I9I6-I9I 8 were certainly of sawback form. The prime evidence for this is the existence of a WFM-made S.98/05mS date-marked for I9 1 8, which must surely have been destined for Constantinople as this weapon stopped being made for the German army in late I9I $7 .{ }^{46}$ To these we might add how several such bayonets have been reported with Ottoman-style numbers on their crossguards, indicating they were around before I928: as Republican Turkey is not known to have received German-made bayonets at any time after April I9I 8, then they must have arrived there before then. What is certain is that before the end of World War One in Europe on II ${ }^{\text {th }}$ November I9I8, WFM had produced at least I,I05,962 of their planned production figure for S.98/ 05 of between one and a half and two million, at a cost to the German government of II,699,609.90 marks. ${ }^{47}$ If we assume that each of the 180,000 or so WFM Gew.98 despatched to the Ottoman Empire came with a company-made bayonet, then some $15.5 \%$ of the entire production were sent there also. In overall terms, 


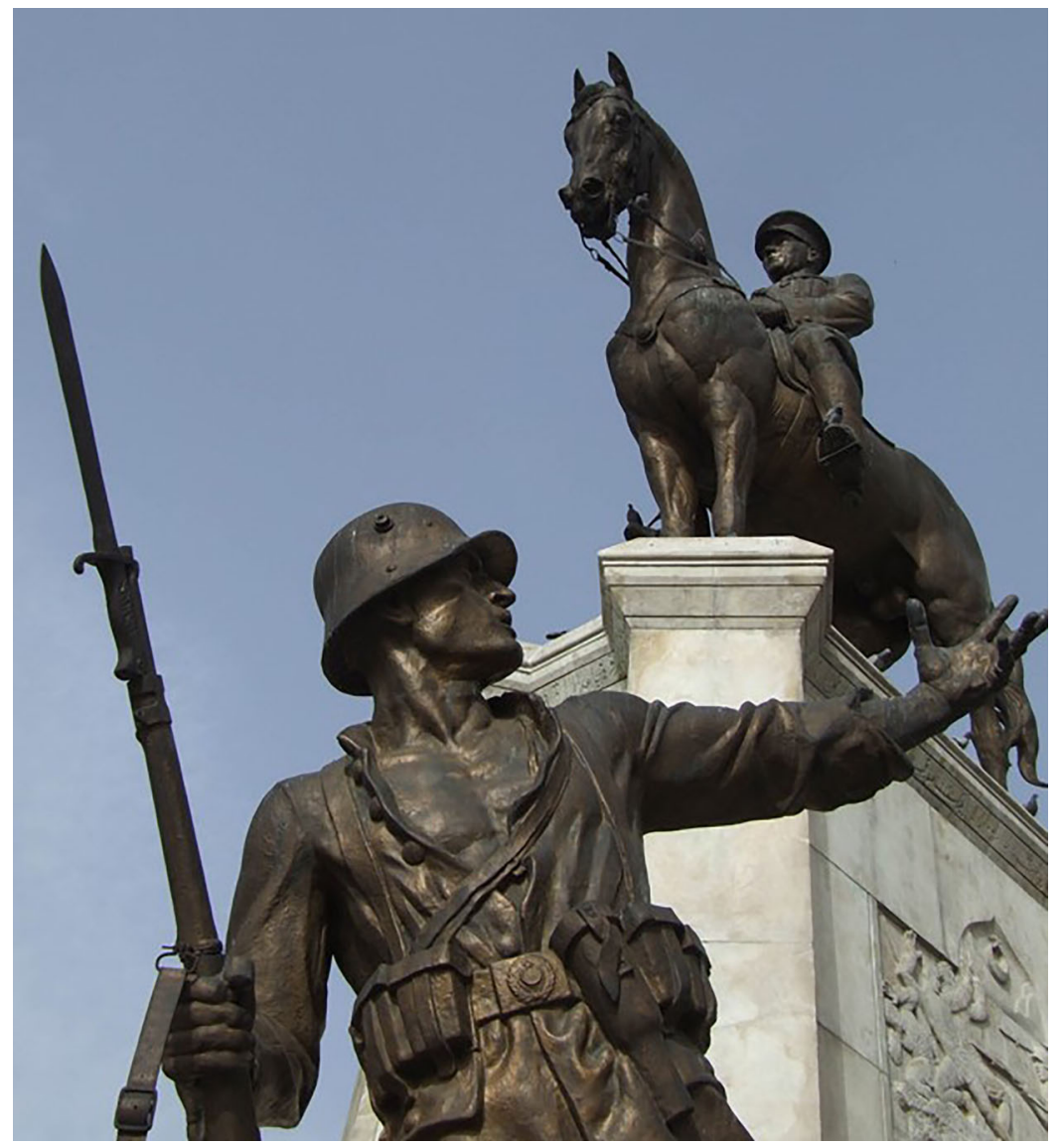

FIGURE 7. One of the soldiers shown on the statue group made by H. Krippel and erected in 1927 in Hakimiyet-i Milliye Meydanı ("Sovereignty of the Nation Square"), Ankara, holding a rifle with a fixed S.98/05 (author's photograph).

though, these weapons had been made available to somewhat less than a quarter of the Ottoman Army at its peak strength of around 700,000. Whether they had arrived in too few numbers and too late to save an increasingly demoralised army is an unanswerable question. All that can be said for certain, is that in theory there were enough around to arm each of the mere I00,000 men that constituted the Ottoman Army when the Armistice of Mudros was agreed on $30^{\text {th }}$ October $1918 .^{48}$ Many of the spares presumably slipped away into private hands, probably with their bayonets also, as examples of the WFM S.98/05 are seen often in the 'antika' shops and bazaars of modern Turkey. ${ }^{49}$

\section{From 1918 to the 1950's}

Part V of the Mudros Treaty demanded the immediate demobilisation of the Ottoman Army, but said nothing about its weaponry. The Treaty of Sèvres of roth 


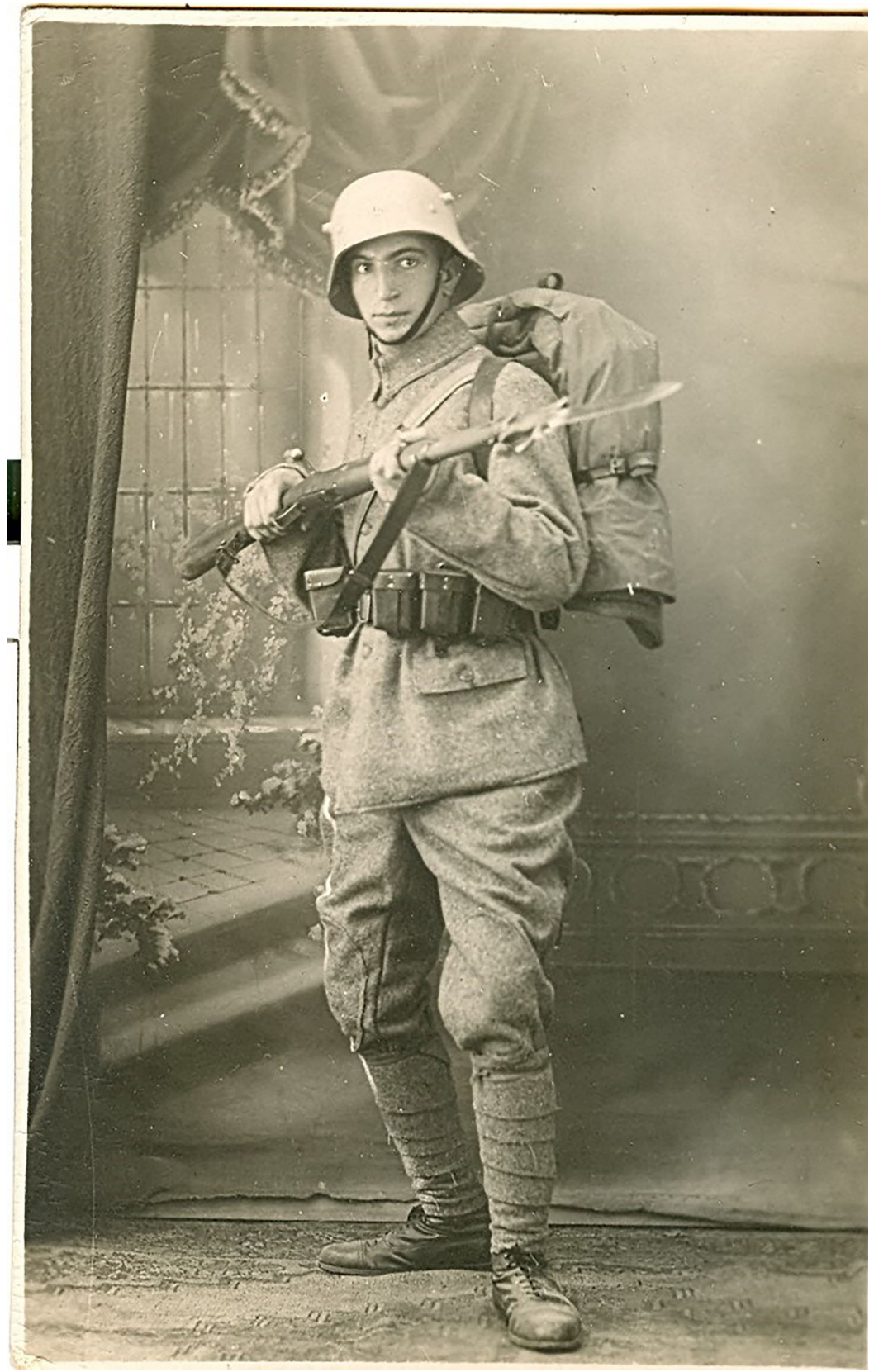

FIGURE 8. A posed photograph of a Turkish soldier en garde with a rifle and fixed S.98/05, dated on the back November 1931 (author's collection).

August, I920, on the other hand, stipulated in its Articles I7 I and I72 the quantities and types of weaponry that could be held in the future by the Turkish armed forces, including the necessary reserve stocks and the weaponry allotted to the Gendarmerie, the rural police force. Article 173 specified further that within six months of the 


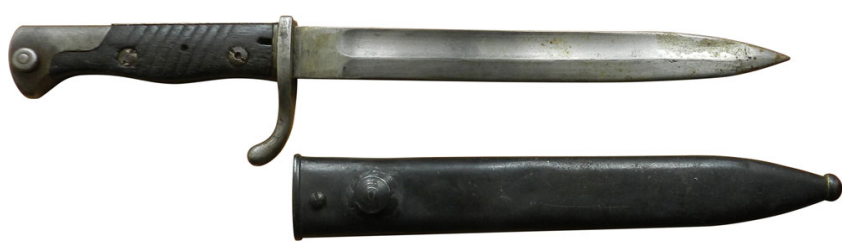

FIGURE 9. A ‘Turked’ Waffenfabrik Mauser S.98/05 and scabbard (author’s photograph).

treaty coming into force any excess weaponry and munitions were to be surrendered to a Military Inter-Allied Commission of Control for this reason under Article 200 of the treaty. These articles, in other words, matched closely the disarmament of Germany as set out in Part V of the Treaty of Versailles.

However, the Treaty of Sèvres was never adopted, being superseded by the Treaty of Lausanne of 1923, which says nothing about Turkish disarmament, a consequence of the recently ended Greek invasion of Anatolia. One result was that those Gew.98 and S.98/05 supplied to Constantinople from I9г6 to I9I 8 had a life-span that greatly exceeded most of their peers that served with the Deutsches Heer. Hence the availability of Gew.98 and their S.98/05 for use by the Republican forces during the Turkish War of Independence (I9I9-1923) and even after. They even feature in one of modern Turkey's most distinctive monuments, the statue group made by H.Krippel and erected in 1927 in the Hakimiyet-i Milliye Meydanı ('Sovereignty of the Nation Square') to celebrate Atatürk's final victory in that war. The free-standing statues of soldiers on each side at the front of the base are each fitted-out with the contemporary model and manufacture German equipment including the Model 17 Stablhelm, and Gew. 98 rifles with fixed S.98/05 (Figure 7), and as shown in a posed photograph of a Turkish soldier dated November I93 I (Figure 8)..$^{\circ 0}$

The explanation for the survival of both the rifles and their bayonets into the I920s and I930s is partly due to a lack of any demand for their surrender except for an allotted number after I9I8-I920. More specifically it was because the WFM bolt-action rifle system was not only one of the most efficient of its kind ever made, still serving as the basis for many modern hunting rifles, but the Turkish Republic simply lacked the financial means necessary to establish its own armaments industry. Although I92 I saw the creation of the Askeri Fabrikalar ('Army Factories', usually abbreviated to AS.FA) as a state-owned holding company on behalf of the new army of the Turkish Republic, followed in $\mathrm{I} 924$ by the founding at Ankara of the Hafif Silah ve Top Tamir Atölyeleri '(Light Arms and Gun Repair Workshop'), ${ }^{\mathrm{I}}$ it was not until 1936 that the Tüfek ve Top Fabrikalar ('Gun and Artillery Factory') was established at Kırıkkale, and not until I93 8 that the first step was initiated there in creating a Turkish-made standard rifle for the Turkish army. ${ }^{52}$ It involved cannibalising, refurbishing, and rebuilding to a standard pattern and calibre the many WFM rifles of all models the Ottoman Empire received between I 887 and I9I 8 in a process that continued until at least 1954 to produce what is often referred to as the 'Turkish Mauser'. ${ }^{53}$ It was only after the involvement of the Turkish Brigade in Korea in 


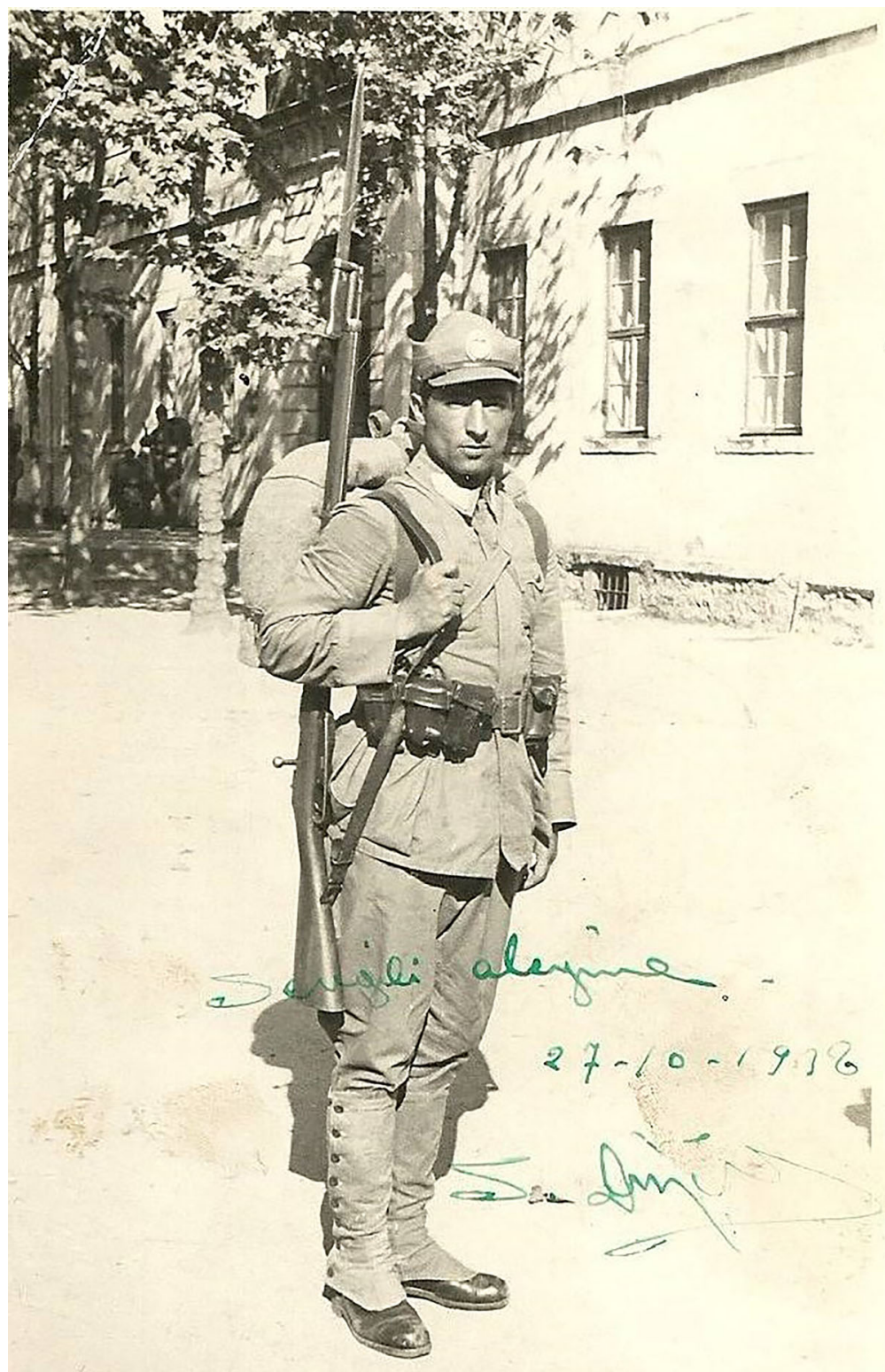

FIGURE 10. A posed photograph of a Turkish soldier with a rifle and full-length 'Ersatz' bayonet, dated on the front 27th October 1936 (supplied by Engin Özturk).

I950, Turkey's 'forgotten war', that the Turkish Armed Forces began to replace their bolt-action 'Turkish Mausers' with a more modern rifle, the 'Garand' MI as then used by the army of the United States of America. ${ }^{54}$

This in turn leads directly to another matter of interest among those who study the bayonets of Ottoman and Republican Turkey. That is to say, when then decision was 
made to shorten stocks of sword- and sword-type bayonets to a more 'fashionable' and more manageable knife-form with a blade length of around $25 \mathrm{~cm} .^{55}$ The result was the shortening of an unknown number of all the types of bayonets Germany had supplied to Turkey, those to fit the WFM Model I887, I890, I893 and I903 rifles, and those that arrived I9I6-I9I8, including examples of the 'Ersatz' and the WFM S.98/05 in its plain and sawback form (Figure 9). The Ottoman army had in fact begun to use short knife-style bayonets in I9I3, with its home-produced Model I9I3, while sometime during World War One an unknown German firm had supplied its own particular version of the Ersatz bayonet to Constantinople for fitting to the Model I903. ${ }^{56}$ Such shortened S.98/05 bayonets, as well as other bayonets supplied to Ottoman Turkey with a blade originally longer than about $25 \mathrm{~cm}$, and often referred to as 'Turked' versions, are often marked AS.FA on the pommel, and/or with Western-style serial numbers, usually on the crossguard. This has suggested to many a conversion programme that perhaps started as early as I928, when Republican Turkey adopted the 'Arabic' numbering system. Photographic evidence refutes this, as it shows Turkish Republican Army soldiers still using long full-length S98/05 and 'Ersatz' bayonets into the I930s (see, e.g., Figure I0), and even as late as May and October I940. The earliest dated photograph known to the writer of a Turkish Republican Army soldier armed with a short bayonet has a handwritten notation indicating it was taken $18^{\text {th }}$ July 1938 , although it is not clear if this is a 'Turked' bayonet or one of the short knife form that - it is commonly believed began to be made at Kurkkkale that same year. Either way, according to A.J.Carter, 'Turkish authorities' stated that the process of bayonet shortening took place I937-I939, but does not provide a precise source for the information. ${ }^{57}$ What is certain is that from I95 I onwards, all the photographs seen by this writer of Turkish soldiers with fixed bayonets on bolt action rifles have the short kind, identifiable in all cases at the Kırıkkale-type. On balance it seems likely that while the shortening programme may have begun in the late I920s, it most probably began immediately before the outbreak of World War Two, probably/perhaps in 1938, when Turkey began the process of producing their own 'Mauser' rifles at the Kırıkkale plant, and along with these their own home-produced knife-bayonets. In other words, the question of when the Turkish army decided on shortening all of its older bayonets then in their armouries remains a matter of debate.

\section{Acknowledgements}

As so often before, I owe a great debt to the staff of Bilkent University, for their help in securing reference material, in particular Fusun Yurdakul (Inter-library Loans). I am grateful also to Evgeni R.Radushev (Department of History, Bilkent University) for his unstinting help with Osmanlıcı matters; Nurzhan Tustikbay (Center for Russian Studies, Bilkent University), for her translations of the relevant sections in В.В.Воронов и Д.Воронов, Штыки Германии 
модели Pfm 7I/98, S98/o2, S98/05 (= V.V.Voronov and D.V.Voronov, German Bayonets Models Pfm 7I/98, S98/02, S98/05) (Moscow, 2016); John M. Ballard (independent researcher), for his continued support in my studies of WWI bayonets and corrections to this text; and my colleagues in the Department of Archaeology at Bilkent University, for their recognition of how the artefacts of the recent past warrant the same attention as those from more ancient periods. I also owe thanks to the many collectors and others in Turkey, the United Kingdom and Europe, and the United States of America, for supplying information on WFM bayonets: it would egregious, however, not to specifically thank Jon Speed among these for sharing his unrivalled knowledge of the unpublished Mauser factory archives; and Henry Yallop and Lisa Traynor, at the Royal Armouries, Leeds, for their forbearance as I examined the German bayonet collections there, which include several WFM examples. Last but not least, I am of course indebted to Henry Yallop, Graeme Rimmer, and a third anonymous reviewer for their contributions in improving the article overall ready for publication, although any mistakes that remain are my own.

\section{Notes}

${ }^{\text {I }}$ E.J.Zürcher, 'Between Death and Desertion: the experience of the Ottoman soldier in World War I', Turcica 28 (I976), 235-58: p. 249.

${ }^{2}$ M.Larcher, La guerre turque dans le guerre mondiale (Paris, I926), 590, with Appendices 44 and 5०; also E.J. Zürcher, 'The Ottoman Conscription System, I844-I9I4', International Review of Social History, 43/3 (I978), 437-49: p. 442-3.

3 Zürcher, 'Ottoman Conscription', p. 447.

${ }^{4}$ E.g. Zürcher, 'Ottoman Conscription', p. 449.

${ }^{5}$ Cf. R.Rhodes James, Gallipoli, (London, I974), p. 348 .

${ }^{6}$ Zürcher, 'Ottoman Conscription', p. 447.

${ }^{7}$ Cf. N.Yorulmaz, Arming the Sultan: German Arms Trade and Personal Diplomacy in the Ottoman Empire (London, 20I4), p.I28.

${ }^{8}$ J.Bennett, 'The 'Aynali Martini': The Ottoman Army's First Modern Rifle', Anatolica 44 (20I8), p. 229-55, provides a detailed analysis of the history of the Peabody-Martini and its use by the Ottoman Army.

${ }^{9}$ Considered as non-obsolescent weapons on account of their calibre, examples of these rifles are only displayed in museums under direct or indirect control by the Turkish Armed Forces.

го то H.B.Danışman (ed.), Gallipoli I915: Bloody Ridge (Lone Pine): Diary of Lt.Mehmed Fasih (İstanbul, 200I), p.27, with Bennett, "Aynali Martini”, p. 249-53, for the recalibration programme, and p. 252 for the rifle's use at Gallipoli.
I Zürcher 'Between Death and Desertion', p. 247 .

${ }^{12}$ Anon. Handbook of the Turkish Army, 8th Provisional Edition (Cairo, I9I6), p. IO, II, and 57, with Bennett, 'Aynali Martini', p. 252.

${ }^{13}$ D.Storz, German Military Rifles 2: Firearms 88 and $9 \mathrm{I}$ (Vienna 20I2), p. I47.

${ }^{14}$ There was no 'Deutsches Heer' or 'German Army' as such in the period of the First Reich (I87I-I9I8), each constituent state controlling its own land and air forces. However, the term is used in the Gesetz betreffend die Verfassung des Deutschen Reiches of I6th April I87I (http://www.documentarchiv.de/ksr/verfksr.html, accessed 30th March 2020), the law establishing the Deutsches Reich (as, e.g. Art. 60, etc.), and is adopted here throughout for convenience.

I5 Storz, German Military Rifles 2, p. I47, although D.B.Webster, Military Bolt Action Rifles, I84I-I9I 8 (Ottowa, I993), p. 43, claims the overall total was 142,600 .

${ }^{16}$ A.J.Carter, German Bayonets III (Norwich, I992), p. 7.

${ }^{17}$ Carter, German Bayonets III, p. 39-54.

${ }^{18}$ Cf. D.Storz, Rifle and Carbine 98: M 98 firearms of German Army from 1898 until I9I 8 (Vienna, 2006), p. I79. As will be shown, many if not all of these were cannibalised and converted into the 'Turkish Mausers' in the late I930's, except for those preserved as presentation pieces, as with those on display at, e.g. the War of Independence Museum in Ankara. Certainly, there are no unconverted examples on display at, e.g. the National Army 
Museum in Istanbul, or the Jandarma Museum in Ankara.

${ }^{19}$ Hence its common name today as the 'Butcher bayonet', although the origin and first use of this term has escaped discovery. It does not appear in any of the World War One soldier's slang books known to the writer.

${ }^{2 \circ}$ F.Ehle, Die Wichtigsten Vorschriften der Truppen zu Fuss des Königreichs Bayern III (Rosenheim I98I), 36.

${ }^{21}$ Ehle, Die Wichtigsten Vorschriften, p.I7. According to S.Thiem, Deutsche Versuchs- und Musterseitengewehre von I895 bis 1945 (Regensburg, 20I4), p. 235, but without providing a source, the Eisenbahntruppen were not issued with the $5.98105 \mathrm{mS}$ until November I908. See also J.Bennett, 'Un engin de torture, une baïonnette à crochets; une arme blanche déshonorée': an historical-archaeological evaluation of the sawback bayonets of the Deutsches Heer', Journal of Conflict Archaeology I4 (2020), on-line at: https://doi. org/IO.IO80/I 5740773.20I9.I730074 (accessed 24th March 2020).

${ }^{22}$ Storz, Rifle and Carbine 98, 352-3. There are many examples of $S .98$ with their blades shortened to between 203 and $305 \mathrm{~mm}$. Carter, German Bayonets I, I 27, believes this was done as part of a deliberate programme for use by the Imperial Navy, as many are by the same maker and have naval markings on them. However, as C.Méry, The German Bayonet (Brazy en Plaine 20I6), 36, and others have noted, examples of these shortened 5.98 have been found on the western front, perhaps used as trench knives. It is reasonable to think that these at least most probably represent examples broken in use, and subsequently shortened.

${ }^{23}$ Nowhere is this specifically stated in any German records the author has seen, although it is noted in French military documents of the time describing the armaments of the Deutsches Heer, while $6 \%$ of each German bayonet production run was for the making of sawbacked versions, a percentage figure that more or less matches the numbers of senior NCO's in a regular German infantry regiment: cf. Bennett, 'Un engin de torture'.

${ }^{24}$ Ehle, Die Wichtigsten Vorschriften III, 36.

25 Ibid.

${ }^{26}$ Storz, Rifle and Carbine 98, p. 362.

${ }^{27}$ Thiem, Deutsche Versuchs- und Musterseitengewehre, p. 257-9; Storz, Rifle and Carbine 98, p. 362-3.

${ }^{28} \mathrm{I}$ am indebted to Jon Speed for a sight of the relevant Mauser factory production documents that provide the following information.
29 Storz, Rifle and Carbine 98, p. 367.

${ }^{3 \circ}$ Usefully summarised in M.Rose, I 2 Inches of Imperial Steel: Sword Bayonets Pattern I 888 and 1903 in British service (Melbourne 2014), p. 75-6.

${ }^{3}$ Storz, Rifle and Carbine 98, p. 356-7, for the Haenel figures; and in Воронов, В.В., и Д.Воронов, Штыки Германии модели Pfm 7I/98, S98/02, S98/05 (= V.V.Voronov and D.V.Voronov, German Bayonets Models Pfm 71/98, S98/o2, S98/o5), Moscow, 2015, p. 2I4-5, for the unmarked example. The XRF analysis of the WFM specimen, a method that does not detect carbon, was done by a benefactor who wishes to remain anonymous using an Olympus Delta Professional Handheld XRF Analyzer.

${ }^{32}$ See, e.g. C.Méry, The German Bayonet, I8981945 (Brazy en Plaine, 20I6), I37, for such a blank for an S.98/05.

33 Cf. Воронов и Воронов, Штыки Германии, p. 2I4-5.

34 The Schutzbleche was a protective shield added to the back of the hilt of all German bayonets after the summer of I9I 5 to prevent the grips from charring if used with the Kar.98 AV, the carbine version of the Gew.98: cf. Carter, German Bayonets I, 27.

${ }^{35} \mathrm{R}$. Boch, 'The rise and decline of flexible production: the cutlery industry of Solingen since the eighteenth century', in C.F.Sabel and J.Zeitlin (edd.), World of Possibilities: Flexibility and Mass Production in Western Industrialization (Cambridge 2002), I53-87: p. I 56-7, with I76, n. 62.

${ }^{36}$ Cf. Boch, as above, p.I55, quoting official contemporary figures indicating some II,O00 of the metal working population at Solingen employed in the 'kotten industrie' as opposed to the 7,000 toiling in the larger steel-making concerns in the area.

37 Carter, German Bayonets I, 9I: although the Coppel and Lüneschloss concerns were relatively new to the making of bayonets, Weyersberg-Kirschbaum had been making them on-and-off since I 883: cf. A.J.Carter, German Bayonets IV, (Norwich I994), 306.

${ }^{8}$ Thiem, Deutsche Versuchs- und Musterseitengewehre, 259.

39 J.Speed, W.Schmid, and R.Herrmann, Mauser: Original Oberndorf Sporting Rifles (Cobourg, Ontario I997) 50, where the year is mistakenly given as I9I4(!), when I9I6 is clearly meant, with Carter, German Bayonets I, 27-8.

${ }^{\circ}$ Storz, Rifle and Carbine 98, p. 368, where it is stated that the first 6,090 examples of Mausermade S.98\%5 were not delivered until May 
I9I6: this strains credulity given how, as we have seen, the company had manufactured no less than $37,55^{\circ}$ examples in December I9I 5 and January I9I6.

${ }^{4 \mathrm{I}}$ For the 'date mark', see below.

${ }^{42} \mathrm{It}$ is likely that Waffenfabrik Mauser consciously produced bayonets above the specified weight to eliminate any possibility of their rejection for being underweight. For the same practice among makers of the British Pattern 1907 bayonet see J.M.Ballard and J.Bennett, 'An Investigation of the Weights of Pattern 1907 Bayonets made in the UK around the First World War Period', Arms and Armour I4:2 (20I7), 206-22: 220.

43 Three only of the other makers of steel scabbards for the S.98/05 marked their products: F.Herder \& Söhne, with their traditional crossed keys over their name; Heinrich Kaufmann \& Söhne, using a mark showing a cat within a near-circle; and Kortenbach \& Rauh, who marked their products 'K\&R'.

${ }^{44}$ Cf. Storz, Rifle and Carbine 98, p. 357.

45 Ibid., p. I79.

${ }^{46}$ The r9I 8 example of a $5.98 / 05 \mathrm{mS}$ is reported in Воронов, В.В.Воронов и Д.Воронов, Штыки Германии модели $\mathrm{Pfm} 7 \mathrm{I} / 98, \mathrm{~S}_{9} 8 / 02$, S98105 (= V.V.Voronov and D.V.Voronov, German Bayonets Models Pfm 7I/98, S98/o2, S98/05), Moscow, 2015, p. 204. Bennett, 'Un engin de torture', discusses the withdrawal of sawback bayonets by the Deutsches Heer.

47 Storz, Rifle and Carbine 98, p. 357.

${ }^{48}$ Larcher, La guerre turque, Appendix 50. The great decline in numbers from around 700,000 in I9I6 or so was not entirely due to deaths in action or by disease, losses that could be madeup to some extent by conscription, but desertion: Zürcher, 'Between Death and Desertion', p. 257, suggests some 500,000 men absconded during the course of the war

49 Although not the rifles! As these use a military-type cartridge their private possession is strictly controlled under Turkish law although examples are known of in private ownership as 'hand-me-downs', usually with the bolts removed and stored elsewhere.

${ }^{\circ} \mathrm{By}$ contrast with the soldiers, shown in uniforms appropriate for the War, Atatürk himself is shown with a Western-style peaked officer's hat, a style not adopted until about 1930 .

${ }^{\text {I }}$ T.F.Yücel, Cumburiyet Türkiye'sinin Sanayileşme Öyküs $\ddot{u}$, (Ankara 2015), p.25, where it is noted how by that time AS.FA. also owned a rice factory!

$5^{2}$ R.Ball, Mauser Military Rifles of the World (5th ed.), (Iola, WI, 20II), p. 389.

53 There is, as yet, no publicly available and comprehensive history of this stage in the Turkish armaments industry, but the overall details have been established by many North American collectors of Mauser rifles who have shared their information with the writer.

${ }^{54}$ M.Uyar and S.Güvenç, 'One Battle and Two Accounts: The Turkish Brigade at Kunu-ri in November I950', The Journal of Military History 80, 20I6: III7-I47: II30, with note 47. It is not certain what bayonet was supplied with this rifle to Turkey, but probably the MI905EI, the usual pattern in USA army use in the Korean War. The Turkish Republic's honour guard still uses the 'Garand' rifle, but fitted with a Turkish-made version of the $\mathrm{M}_{5}$ bayonet of 1953 , with an aluminium hilt.

55 The section on 'Turked' S.98/05 in D.Ottobre, Observations on Turkish Bayonets, Newcommerstown, $\mathrm{OH}, \quad 20 \mathrm{I}_{3}$, contains photographs of some 50 or more examples of these modified in one way or another to suit the demands of the Turkish Army.

${ }^{56}$ For the Turkish Model I9I3, see Ottobre, Observation; for the Turkish 'Ersatz', A.J.Carter, German Ersatz Bayonets I, Brighton I975, p. $55^{-6 .}$

57 A.J. Carter, German Ersatz, p. 55.

\section{Notes on contributor}

Julian Bennett is a Fellow of the Society of Antiquaries of London. Having received his BA in Archaeology at the University of Durham, UK, he was subsequently awarded a PhD by the University of Newcastle upon Tyne, UK, for his research on Hadrian's Wall. An Associate Professor in the Department of Archaeology at İhsan Doğramacı Bilkent University in Ankara, Turkey, he combines his studies in Roman archaeology with research into the bayonets and other artefacts of the Great War. 
ORCID

Julian Bennett (1D http://orcid.org/o0oo-0002-6569-423X

Correspondence to: Julian Bennett. Email: bennett@bilkent.edu.tr. 